\section{Skjebnens spill}

Philip Roth

Nemesis

280 s. New York, NY: Houghton Mifflin Harcourt, 2010. Pris USD 26

ISBN 978-0-547-31835-6

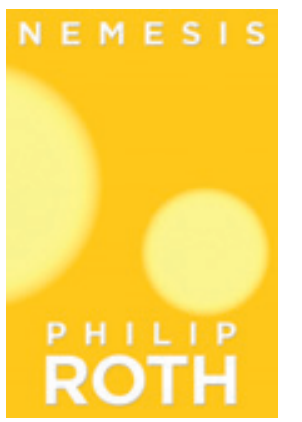

De mange poliomyelittepidemiene i første halvdel av det 20. århundre hadde dimensjoner og følger som vi knapt forstår i dag. Friske, lekende barn kunne så å si over natten miste førligheten og i verste

fall også livet. Smittemønsteret var uforståelig, og det fantes verken behandling eller effektive forebyggingstiltak. Det største utbruddet her i landet fant sted i 1951, med over 2100 tilfeller av hjernehinnebetennelse eller lammelser. Vaksinasjonen startet først opp i 1956 (1).

I sin seneste bok, Nemesis, gir Philip Roth en detaljert beskrivelse av en polioepidemi i Newark i 1944 og den dramatikken som sykdommen førte med seg. Hovedpersonen er den 23-årige atleten Bucky Cantor som hadde for dårlig syn til å dra i krigen. Som gymnastikklærer og aktivitetsleder for barn og ungdom, ser han hvordan smitten og panikken sprer seg i nabolaget. Den unge idealisten tar på seg en oppgave og et ansvar som går langt utover det gjennomsnittlige. «It isn't a matter of doing - it's a matter of being there», sier han om sine forsøk på å trøste og hjelpe.

Men selv om sykdom og smitte, frykt og fortvilelse fyller de fleste sidene, er det ikke poliomyelitt denne boken egentlig handler om. Den handler om menneskers samvittighet og skyldfølelse, og først og fremst om skjebnens spill slik tittelen henspiller på.

Philip Roth (f. 1933) er en fortellingens mester. Hans bøker, som ofte tar utgangspunkt i det jødiske immigrantmiljøet i Newark der han selv vokste opp, er både humoristiske og tankevekkende. Og ikke minst er de velformulerte. Han belyser sider ved den menneskelige naturen i sin alminnelighet og det amerikanske samfunnet i særdeleshet. Philip Roth skriver simpelthen bøker som gjør at vi kan forstå verden omkring oss bedre. Et 30-talls romaner gjennom de siste 50 årene har gjort ham til en av USAs mest prisbelønte forfattere. Selv har jeg størst sans for bøkene om hans mest kjente «alter ego», forfatteren Nathan Zuckerman.

Nemesis er en av Roths korte, frittstående romaner. Den er lettlest og gripende. Gjennom 240 sider følger vi Bucky Cantors kamp med seg selv. Men det er gjennom de siste 40 sidene at mesterens litterære grep løfter boken opp til det ekstraordinære.

Fortsatt håper jeg på en nobelpris til en forfatter som har etterlatt seg så mye leseglede. Om ikke for Nemesis, så i hvert fall for et imponerende forfatterskap.

\section{Magne Nylenna}

Helsebiblioteket

\section{Litteratur}

1. Flugsrud LB, Nøkleby H. 50 år med poliovaksine i Norge. Tidsskr Nor Lægeforen 2006; 126: 3251.

\section{Høyere, raskere, sterkere}

Per Fugelli

Døden, skal vi danse?

248 s, ill. Oslo: Universitetsforlaget, 2010. Pris NOK 319

ISBN 978-82-15-00907-0

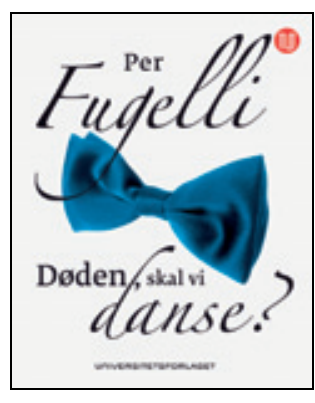

Per Fugelli ville skrive en bok der han gjenopplivet døden, og der tabuet rundt død ble fjernet til fordel for en åpenhet for at døden finnes som en naturlig del av tilværelsen. For å samle stoff om

hvordan mennesker lever med døden andre steder, reiste Fugelli til Afrika våren 2009.

Der ble han etter hvert syk, og tilbake i Norge viste det seg at plagene ikke kom fra en tropisk infeksjonssykdom, men fra tykktarmskreft med spredning til lungen. Bokprosjektet ble endret, som Fugelli skriver, fra teori til praksis, fra abstraksjon til person.

Boken er inndelt i ni kapitler, og vi hører vekselvis samfunnsmedisineren Fugelli og den alvorlig syke Per. Samfunnsmedisineren gir oss en beskrivelse av det norske velferdssamfunnet og vår holdning til sykdom og død. Eksempler på vår tids forakt for svakhet, sykdom og avhengighet blir sammenliknet med mer helhetlig syn på livet og menneskene. Som den skarpe debattanten han er, velger Fugelli seg ekstreme eksempler fra Norge, USA og Afrika. Han viser samtidig hvordan det han kaller vår tids prestasjonskultur, kommer til uttrykk som dødsfornektelse. Døden er ekstremformen for svakhet, en provokasjon mot kapitallivets prioritet, og en nullvisjon for død blir derfor et mål for helsevesenet og samfunnet for øvrig.

Den alvorlig syke Per gir oss et innblikk i ulike sider ved sykerollen. Tross en kjærlighetserklæring til det norske helsevesenet forteller han om manglende menneske-

lighet, fravær av kontinuitet og en følelse av kaos i møte med spesialisthelsetjenesten.
Det er en innholdsrik bok. Både Kreftforeningens spesialiserte pasientforeninger, medikaliseringen og profesjonaliseringen av døden, og venner og bekjentes velmente, men beklemmende oppførsel blir drøftet. En stor del vies ulike måter å forholde seg til døden. Vår redsel for døden er forståelig, sier Fugelli. Samtidig er det nødvendig å minne oss på konsekvenser ved fravær av død.

Per Fugelli er kjent for en polemisk stil og kan til tider være svart-hvitt i sin argumentasjon. I denne boken synes jeg imidlertid han klarer å få frem et veldig klart budskap, samtidig som han viser det ambivalente i å være for en gjenoppliving av døden og sitt eget sterke ønske om å leve lenge. Dette er flott formulert som å lete etter nokpunktet for liv, ikke jage etter nullvisjonen for død.

Målgruppen er ikke spesielt helsepersonell, og boken kan leses av alle som er interessert i helsepolitikk og utviklingen av velferdssamfunnet mot et sorteringssamfunn. Det er en nyttig vekker for leger, ikke minst oss onkologer og palliatører, og jeg anbefaler den sterkt til helseøkonomer og planleggere som et vitnesbyrd om hva effektiviseringen i spesialisthelsetjenesten koster for den enkelte pasient.

\section{Lotte Rogg}

Kreftsenteret

Oslo universitetssykehus, Ullevål

\section{De spesielle hjerner og savantsyndromet}

Darold A. Treffert Islands of genius

The bountiful mind of the autistic, acquired and sudden savant. 302 s, ill. London: Jessica Kingsley Publishers, 2010. Pris GBP 20 ISBN 978-1-84905-810-0

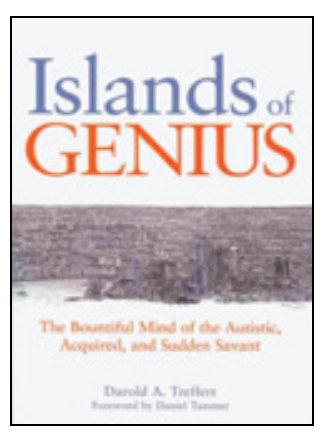

Interessen for savantsyndromet eksepsjonelle (geniale) egenskaper innenfor visse felter hos personer med atferdsforstyrrelser og tegn til hjerneskade - har økt både blant nevrobiologer og i media. Syndromet finnes hos kanskje $10 \%$ av autistene, og halvparten av alle savanter er autister. Det er fire ganger så mange mannlige som kvinnelige autister, og denne forskjellen øker til seks til én blant savantene. Syndromet er oftest medfødt, men kan også dukke opp etter enkelte hjerneskader. De helt spesielle talentene gjelder 
nesten alltid kalendarisk kalkulasjon («hvilken ukedag faller 1. mai på i 4020?»), andre matematiske kalkulasjoner, musikk, tegning og maling og ekstrem hukommelse, særlig for tabeller og rekker av tall.

Darold Treffert er kanskje verdens mest profilerte ekspert på savantsyndromet. Han var faglig rådgiver for Dustin Hoffman $\mathrm{i}$ hans utforming av verdens mest kjente savant: Raymond Babbitt i filmen Rain Man. Treffert har skrevet en rekke bøker om fenomenet, deltatt i et utall av filmer og TV-produksjoner omkring det samme og er sentral i kretsen rundt www.savantsyndrome.com.

Islands of genius er en oppsummering av hans snart 50-årige erfaring med savanter. Boken er delt i fem deler. I den første delen beskriver han selve syndromet med en rekke forbløffende eksempler. Del to er kasuistikker som beskriver over 20 savanter. I del tre skildrer han ervervede savantegenskaper etter hjerneskader eller sykdommer. Han diskuterer også de plutselig oppståtte savanter, avgrenser fenomenet mot «nevronormale» talentfulle mennesker og har noen tankevekkende betraktninger over mulighetene for at vi alle har visse savantegenskaper gjemt $i$ vår hjerne. I del fire gir forfatteren råd til foreldre, pårørende og lærere som får en savant nært innpå seg, mens del fem er hans egne betraktninger over hvordan studiet av savantfenomenet kan bringe nevrobiologi og forskning videre.

Målgruppen er forst og fremst en leserkrets som har en viss nevrobiologisk bakgrunn, men boken kan leses med betydelig utbytte av alle leger og antakelig også et legepublikum. Treffert diskuterer meget innsiktsfullt mulighetene for at vi alle har savantegenskaper, at savantisme antakelig er et «release-fenomen», hvor venstre hemisfæres kontroll over høyre blir svekket. Særlig erfaringene fra ervervede savanter og MR-undersøkelser av autistiske savanter gir holdepunkter for at en skade i venstre, fremre temporallapp er en fellesnevner. Han begrunner den mannlige overtalligheten med at testosteron i store doser kanskje er skadelig for den vulnerable venstre hemisfæren i føtallivet. Forfatteren filosoferer over at barn med savantegenskaper «kan gjøre ting de ikke har lært», f.eks. å spille avanserte klassiske pianostykker uten å ha hatt en eneste time med musikkundervisning enn si har spilt piano før. Han postulerer meget overbevisende at det må finnes en nedarvet «genhukommelse» for ervervede egenskaper.

Denne anmelderen har hatt en storartet opplevelse ved å lese denne boken og anbefaler den på det varmeste til alle kolleger.

\section{Ragnar Stien}

Oslo

\section{Dansens nevrobiologi}

Bettina Bläsing, Martin Puttke,

Thomas Schack, red.

\section{The neurocognition of dance}

Mind, movement and motor skills. $249 \mathrm{~s}$, tab, ill. Hove: Psychology Press, 2010. Pris GBP 45 ISBN 978-1-84872-024-4

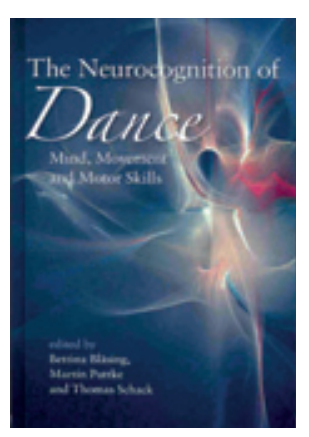

Å lage en bok om det hittil ikke eksisterende fagfeltet dansens nevrobiologi ville for noen år siden ha virket som et litt pussig, konstruert prosjekt. Noe av den mest spennende nevrobiologiske forskningen i det siste tiåret har imidlertid dreid seg om forsøkene på å forstå den tette koblingen mellom sansing, emosjon, kognisjon og motorikk. Slagordpreget sagt ser vi en kroppsliggjøring av sinnet og en sinnliggjøring av kroppen. I lys av dette føyer denne boken seg inn i rekken av flere liknende tverrvitenskaplige prosjekter.

Boken har sitt utspring i en tysk konferanse som i 2007 brakte sammen dansere, koreografer, bevegelsesforskere og nevrobiologer. Dette har resultert i en bok som kan ses på som et forsøk på forståelse av planlegging og kognitiv representasjon av dans, av hvordan vi oppfatter, tolker og lærer bevegelse og av den estetiske nytelsen vi opplever ved å se og utføre dans. De tre redaktørene har sin bakgrunn fra henholdsvis bevegelsesforskning og nevrovitenskap (Bläsing og Schack) og ballett og ballettkoreografi (Puttke). De ulike bidragsyterne spenner også vidt i faglig bakgrunn, fra nevrobiologi og biomekanikk til pedagogikk, psykologi, utøvende dans og koreografi.

Tematisk er boken inndelt $i$ tre. I en innledende del tar man for seg nevrobiologisk forståelse av kontroll av bevegelser og presenterer ulike perspektiver på hvordan bevegelser planlegges, initieres og lagres $i$ hjernen. I del to presenterer dansere, koreografer og pedagoger sine tilnærminger til, og praktiske erfaringer med, hvordan dans relaterer seg til kognitive og mentale prosesser. Den avsluttende delen er viet til de relativt få nevrobiologiske studiene som finnes av dans og dansere. Så å si alle kapitlene har fyldige referanselister, og registeret er godt. Det er enkelte illustrasjoner i sorthvitt, men med unntak av omslaget, fremstår layouten som ganske kjedelig.

Styrken er først og fremst enkeltkapitlene. I kapittel fire gjennomgår man på oversiktlig vis modeller og empiriske studier omkring mentale representasjoner av motorisk kontroll og av hukommelse for motorikk. I den midtre delen er særlig
Puttkes bidrag, Learning to dance means learning to think, svært interessant. Koreografen Gregor Zölligs bidrag, Searching for that «other land of dance», er også fascinerende. Zöllig gjennomgår de ulike fasene, ideene og improvisasjonen som utgjør koreograferingens kreative prosess. I det åttende, og etter min mening det beste, kapitlet gjennomgår Beatriz Calvo-Merino den sannsynlige betydningen av hjernens speilnevronsystemer for opplevelsen av dans. Dermed bringer hun også inn en ofte oversett synsvinkel, nemlig tilskuerens. Tittelens antydning om et integrativt perspektiv oppfylles forst og fremst $i$ dette kapitlet.

Selv om man forklarer både undersøkelsesteknikker og fagtermer fortløpende i de «vitenskapelige» kapitlene, vil nok lesere uten biomedisinsk bakgrunn fort falle av lasset her. Den største svakheten er imidlertid at det integrative perspektivet ikke er helt overbevisende. Slik sett bør boken ses som et første arbeidsdokument for en videre utforskning av feltet. For undertegnede, med bakgrunn fra nevrofagene, er flere av enkeltkapitlene likevel fascinerende lesning, og jeg kan anbefale boken til alle kolleger med interesse for dans, og for koblingen mellom sansing, emosjon, kognisjon og motorikk.

\section{Are Brean}

Tidsskriftet

\section{Å kommunisere vitenskapelige resultater}

Thomas A. Lang

How to write, publish, and present in the health sciences

A guide for clinicians and laboratory researchers. 389 s, tab, ill. Philadelphia, PA: APC Press, 2009. Pris USD 60 ISBN 978-1-934465-14-1

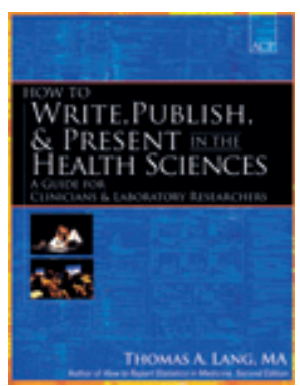

Formidling av vitenskapelige forskningsresultater blir stadig viktigere. I økende grad er forskningsaktivitet, -produksjon og -formidling blitt et finansielt anliggende for forskningsgrupper og institusjoner - også utenfor de tradisjonelle universitetsrammene. For de større helseforetakene spiller forskningsaktivitet en viktig rolle. Kvalitet og kvantitet blir forsøkt målt og vektet med mer eller mindre egnede metoder. Uansett, forskningsaktiviteten blir forsøkt kommunisert på en smart måte - ikke bare for å formidle det faglige, 